\title{
THE EFFECT OF ALPHA LIPOIC ACID ON IDIOPATHIC ASTHENOZOOSPERMIC PATIENTS
}

By

\author{
Ahmed N. M. Abd El-Hamid, Yahya M. I. Hodeeb, Emad M. El-Rewiny \\ and Abdullah M. Gaafar* \\ Departments of Dermatology \& Andrology and Clinical Pathology*, Faculty of Medicine, \\ Al-Azhar University, Egypt \\ Corresponding Author: Ahmed Nabil Mohammed Abd El-Hamid Zayed, \\ E-mail: zayed3_6@hotmail.com
}

\begin{abstract}
Background: Many infertile men have disorders correctable with the use of medication, and if diagnosed and treated properly, natural fertilization can be attained.

Objective: To evaluate the effect of ALA on semen parameters in idiopathic asthenozoospermia.

Patients and methods: This was a case-control study, including 80 patients presenting with primary infertility enrolled from outpatient Andrology Clinic Units of Al-Azhar University Hospitals. Patients were divided into two equal groups. One group was given oral ALA tablets at a dose of $300 \mathrm{mg}$ twice/day, whereas the other group was given a placebo twice daily. The duration of the study ranged from March 2020 till September 2020.
\end{abstract}

Results: There was a significant difference between 2 groups as regard total motility after treatment progressive motility after treatment, and \% vitality after treatment.

Conclusion: Medical therapy of asthenoteratospermia with ALA supplement could improve quality of semen parameters.

Keywords: Reproductive, Infertility, ALA, Semen, and Asthenozoospermia.

\section{INTRODUCTION}

Asthenozoospermia is a condition in which the percentage of progressively motile sperm is abnormally low. In men, it is defined as less than $25 \%$ rapid motility or less than $50 \%$ progression in a semen sample (Lu et al., 2010).

Alpha-lipoic acid (ALA) is one of the most powerful biological antioxidants and is considered as a "universal antioxidant" due to both water and fat solubility. This antioxidant can easily penetrate different tissues, cells and even organelles such as mitochondria as main engine driving ROS production. Alpha-lipoic acid is an organo-sulphur compound (di-thiol) derived from octanoic acid and acts as a necessary cofactor for many enzymes. It can salvage other endog-enous (enzymatic and nonenzymatic) antioxidants such as oxidized vitamin $\mathrm{C}$, glutathione, vitamin E, Coenzyme Q10 and even more (Borowczyk et al., 2015).

ALA has been used successfully in experimental animals to protect against the oxidative stress induced by X-ray and chemotherapeutic agents (Manda et al., 2011). 
The aim of the study was to evaluate the effect of ALA on semen parameters in idiopathic asthenozoospermia.

\section{PATIENTS AND METHODS}

This was a clinical trial, carried at outpatient Andrology clinic units of AlAzhar University Hospitals from December 2019 till June 2020 eighty patients presenting with primary infertility were divided into two equal groups; 40 ALA and 40 placebo groups.

\section{Inclusion criteria:}

Infertile patients (more than 1 year) with asthenozoospermia (low motility: less than $32 \%$ progressive motility and less than $40 \%$ progressive and no progressive motility), normal FSH and testosterone levels.

\section{Exclusion criteria:}

Azoospermic patients, smoking, varicoceles patients (no varicocele by clinical examination \& duplex), gonadotoxins and anti-androgens, alcoholics, endocrinal or genetic disorders, genitourinary tract infections chemotherapy and infertility therapy for 1 year.

Patients were subjected to history, physical examination and Semen analyses. The sample was collected after a minimum of 2 days and a maximum of 7 days of sexual abstinence. The result of semen analysis was compared to the standard values for semen analysis according to the criteria of $\mathrm{Lu}$ et al.
(2010). Colorimetric method was used for analyzing seminal total antioxidant capacity (TAC; biodiagnostic) (Khosrowbeygi et al., 2012).

Total anti-oxidant capacity was measured in seminal plasma before the study and after treatment course for the two stuied groups.

Intervention: One group was given oral ALA tablets at a dose of $300 \mathrm{mg}$ twice/day (Thiotacid $300 \mathrm{mg}$; Eva Company, Cairo, Egypt), whereas the other group was given a placebo twice daily. The duration of therapy for both groups was 3 months; semen analysis was assessed again in each group after termination of treatment.

An informed verbal consent from every participant was obtained.

\section{Statistical analysis:}

Data were fed to the computer and analyzed using IBM SPSS software package version 20.0. (Armonk, NY: IBM Corp) Qualitative data were described using number and percent. The Kolmogorov-Smirnov test was used to verify the normality of distribution Quantitative data were described using range (minimum and maximum), mean, standard deviation, median and interquartile range (IQR). Significance of the obtained results was judged at the 5\% level. 


\section{RESULTS}

This table shows that there were significant difference between 2 groups as regard occupation and there were high significant difference between 2 groups as regard duration of marriage (Table 1).

Table (1): Comparison between the two studied groups according to demographic data

\begin{tabular}{|c|c|c|c|c|c|}
\hline \multirow{2}{*}{ Parameters Groups } & \multicolumn{2}{|c|}{$\begin{array}{c}\text { Group A } \\
(n=40)\end{array}$} & \multicolumn{2}{|c|}{$\begin{array}{c}\text { Group B } \\
(\mathrm{n}=\mathbf{4 0})\end{array}$} & \multirow[t]{2}{*}{$\mathbf{P}$} \\
\hline & No. & $\%$ & No. & $\%$ & \\
\hline \multicolumn{6}{|l|}{ Age (years) } \\
\hline $20-30$ & 13 & 32.5 & 5 & 12.5 & \multirow{3}{*}{$\begin{array}{l}{ }^{\mathrm{MC}} \mathrm{p}= \\
0.077\end{array}$} \\
\hline $30-40$ & 23 & 57.5 & 32 & 80.0 & \\
\hline$>40$ & 4 & 10.0 & 3 & 7.5 & \\
\hline Min. - Max. & \multicolumn{2}{|c|}{$25.0-41.0$} & \multicolumn{2}{|c|}{$27.0-41.0$} & \multirow{3}{*}{0.216} \\
\hline Mean \pm SD. & \multicolumn{2}{|c|}{$33.88 \pm 5.35$} & \multicolumn{2}{|c|}{$35.18 \pm 3.86$} & \\
\hline Median (IQR) & \multicolumn{2}{|c|}{$35.50(29.0-38.0)$} & \multicolumn{2}{|c|}{$36.0(33.0-38.0)$} & \\
\hline \multicolumn{6}{|l|}{ Residence } \\
\hline Urban & 8 & 20.0 & 9 & 22.5 & \multirow{2}{*}{0.785} \\
\hline Rural & 32 & 80.0 & 31 & 77.5 & \\
\hline \multicolumn{6}{|l|}{ Education Status } \\
\hline Less than high school & 10 & 25.0 & 7 & 17.5 & \multirow{3}{*}{0.670} \\
\hline High school & 23 & 57.5 & 24 & 60.0 & \\
\hline Bachelor degree & 7 & 17.5 & 9 & 22.5 & \\
\hline \multicolumn{6}{|l|}{ Occupation } \\
\hline Worker & 4 & 10.0 & 7 & 17.5 & \multirow{3}{*}{0.041} \\
\hline Employee & 20 & 50.0 & 27 & 67.5 & \\
\hline Professional & 16 & 40.0 & 6 & 15.0 & \\
\hline \multicolumn{6}{|l|}{ Duration of marriage } \\
\hline Min. - Max. & \multicolumn{2}{|c|}{$2.0-6.0$} & \multicolumn{2}{|c|}{$2.0-9.0$} & \multirow{3}{*}{0.001} \\
\hline Mean \pm SD & \multicolumn{2}{|c|}{$4.20 \pm 1.42$} & \multicolumn{2}{|c|}{$5.73 \pm 2.14$} & \\
\hline Median (IQR) & \multicolumn{2}{|c|}{$4.0(3.0-5.0)$} & \multicolumn{2}{|c|}{$6.0(4.0-7.50)$} & \\
\hline
\end{tabular}

$\chi 2$ : Chi square test, MC: Monte Carlo, t: Student t-test, U: Mann Whitney test

$\mathrm{p}$ : $\mathrm{p}$ value for comparing between the studied groups, *: Statistically significant at $\mathrm{p} \leq 0.05$

Group A: cases group, Group B: placebo group

There is high significant difference between 2 groups as regard volume after treatment and there is significant difference between 2 groups as regard count before treatment and there is high significant difference between 2 groups as regard count after treatment. There is high significant difference between 2 groups as regard total motility after treatment and as regard progressive motility after treatment and as regard \% vitality after treatment (Table 2). 
AHMED ABD EL-HAMID et al.,

Table (2): Comparison between the two studied groups according to semen analysis

\begin{tabular}{|c|c|c|c|c|}
\hline \multicolumn{2}{|c|}{$\begin{array}{ll}\text { Semen analysis } & \text { Groups } \\
\end{array}$} & $\begin{array}{c}\text { Group A } \\
(n=40)\end{array}$ & $\begin{array}{c}\text { Group B } \\
(n=40)\end{array}$ & $\mathbf{p}$ \\
\hline \multirow{3}{*}{$\begin{array}{l}\text { Volume } \\
\text { (ml) }\end{array}$} & $\begin{array}{l}\text { Before treatment } \\
\text { Mean } \pm S D\end{array}$ & $1.80 \pm 0.64$ & $1.76 \pm 0.70$ & 0.786 \\
\hline & $\begin{array}{l}\text { After treatment } \\
\text { Mean } \pm \text { SD. }\end{array}$ & $2.86 \pm 0.79$ & $1.75 \pm 0.70$ & $<0.001$ \\
\hline & ${ }^{\mathbf{t} 1} \mathbf{p}_{1}$ & $<0.001$ & 0.479 & \\
\hline \multirow{3}{*}{ Count $\times 10^{6} / \mathrm{ml}$} & $\begin{array}{l}\text { Before treatment } \\
\text { Mean } \pm \text { SD. }\end{array}$ & $15.17 \pm 9.61$ & $20.27 \pm 10.18$ & 0.031 \\
\hline & $\begin{array}{l}\text { After treatment } \\
\text { Mean } \pm \text { SD. }\end{array}$ & $47.96 \pm 12.84$ & $20.26 \pm 10.36$ & $<.0001$ \\
\hline & ${ }^{\mathrm{z}} \mathbf{p}_{1}$ & $<0.001$ & 0.886 & \\
\hline \multirow{3}{*}{$\begin{array}{c}\text { Morphology } \\
(\%)\end{array}$} & $\begin{array}{c}\text { Before treatment } \\
\text { Mean } \pm \text { SD. }\end{array}$ & $3.97 \pm 1.33$ & $3.73 \pm 1.34$ & 0.421 \\
\hline & $\begin{array}{c}\text { After treatment } \\
\text { Mean } \pm \text { SD. }\end{array}$ & $4.59 \pm 1.86$ & $3.71 \pm 1.35$ & 0.064 \\
\hline & $\mathbf{z}_{\mathbf{p}_{1}}$ & 0.151 & 0.108 & \\
\hline \multirow{3}{*}{$\begin{array}{c}\text { Total Motility } \\
(\%)\end{array}$} & $\begin{array}{l}\text { Before treatment } \\
\text { Mean } \pm \text { SD. }\end{array}$ & $27.26 \pm 13.59$ & $23.49 \pm 13.07$ & 0.211 \\
\hline & $\begin{array}{c}\text { After treatment } \\
\text { Mean } \pm \text { SD. }\end{array}$ & $54.29 \pm 8.51$ & $23.71 \pm 13.68$ & $<0.001$ \\
\hline & ${ }^{\mathbf{z}_{\mathbf{p}_{1}}}$ & $<0.001$ & 0.619 & \\
\hline \multirow{3}{*}{$\begin{array}{c}\text { Progressive } \\
\text { Motility } \\
(\%)\end{array}$} & $\begin{array}{l}\text { Before treatment } \\
\text { Mean } \pm \text { SD. }\end{array}$ & $20.69 \pm 9.11$ & $17.85 \pm 9.27$ & 0.182 \\
\hline & $\begin{array}{c}\text { After treatment } \\
\text { Mean } \pm \text { SD. }\end{array}$ & $42.43 \pm 5.25$ & $18.07 \pm 9.56$ & $<0.001$ \\
\hline & ${ }^{\mathbf{z}} \mathbf{p}_{\mathbf{1}}$ & $<0.001$ & 0.064 & \\
\hline \multirow{3}{*}{$\%$ Vitality } & $\begin{array}{l}\text { Before treatment } \\
\text { Mean } \pm \text { SD. }\end{array}$ & $61.79 \pm 13.45$ & $58.62 \pm 14.91$ & 0.320 \\
\hline & $\begin{array}{l}\text { After treatment } \\
\text { Mean } \pm \text { SD. }\end{array}$ & $71.53 \pm 9.24$ & $58.34 \pm 14.90$ & $<0.001$ \\
\hline & ${ }^{\mathbf{t 1}} \mathbf{p}_{1}$ & $<0.001$ & 0.125 & \\
\hline
\end{tabular}

t: Student t-test, U: Mann Whitney test, t1: Paired t-test, Z: Wilcoxon signed ranks test

$p: p$ value for comparing between the studied groups, $p 1: p$ value for comparing between Before treatment and After treatment

Group A: cases group, Group B: placebo group

There was a significant difference between 2 groups as regard fructose after treatment and as regard $\mathrm{PH}$ after treatment and as regard pus cells after treatment (Fig 1 and 2). 
THE EFFECT OF ALPHA LIPOIC ACID ON IDIOPATHIC...

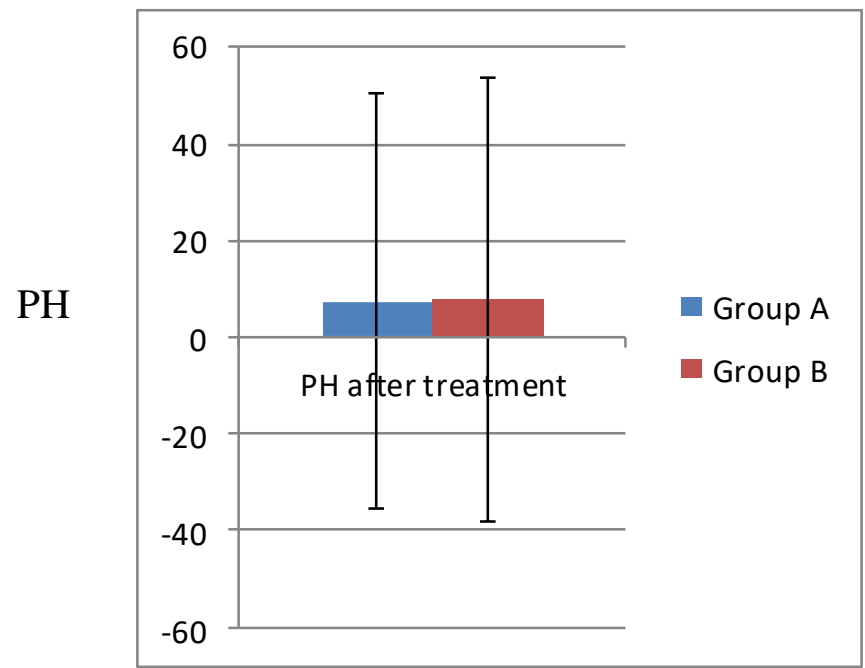

Groups

Figure (1): Comparison between the two studied groups according to PH after treatment

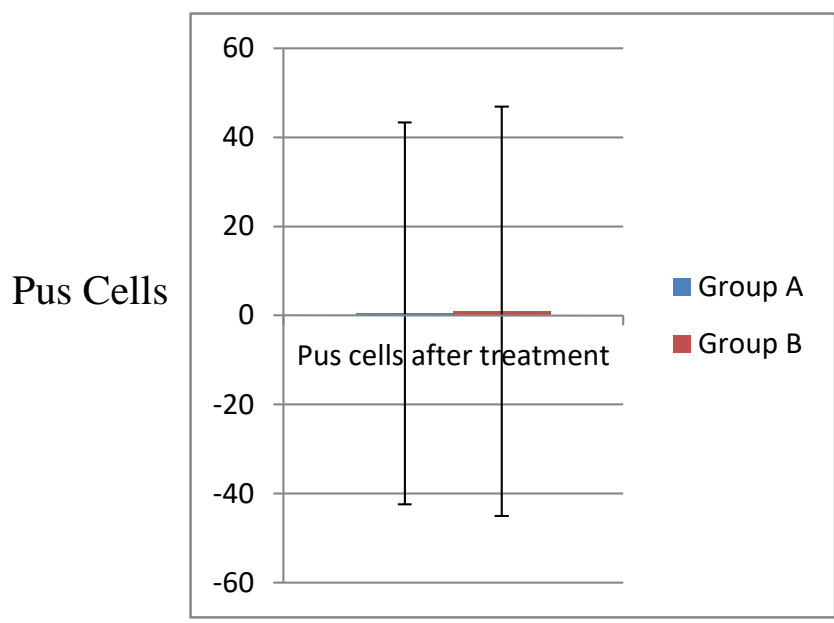

Groups

Figure (2): Comparison between the two studied groups according to pus cells after treatment

This table shows that there is high significant difference between 2 groups as regard TAC after treatment (Table 3).

Table (3): Comparison between the two studied groups according TAC

\begin{tabular}{|c|c|c|c|c|}
\hline \multicolumn{2}{|c|}{ Parameters $\quad$ Groups } & $\begin{array}{c}\text { Group A } \\
(\mathrm{n}=\mathbf{4 0})\end{array}$ & $\begin{array}{c}\text { Group B } \\
(n=40)\end{array}$ & $\mathbf{p}$ \\
\hline \multirow{9}{*}{ 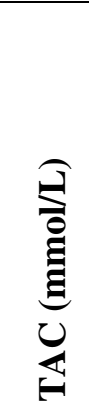 } & Before treatment & & & \\
\hline & Min. - Max. & $0.44-1.79$ & $0.45-1.85$ & \multirow{3}{*}{0.517} \\
\hline & Mean \pm SD & $1.15 \pm 0.41$ & $1.21 \pm 0.39$ & \\
\hline & Median (IQR) & $1.27(0.77-1.48)$ & $1.14(0.96-1.54)$ & \\
\hline & After treatment & & & \\
\hline & Min. - Max. & $1.13-2.43$ & $0.42-1.89$ & \multirow{3}{*}{$<0.001^{*}$} \\
\hline & Mean \pm SD. & $1.79 \pm 0.37$ & $1.20 \pm 0.40$ & \\
\hline & Median (IQR) & $1.77(1.46-2.13)$ & $1.16(0.96-1.55)$ & \\
\hline & ${ }^{t 1} \mathbf{p}_{1}$ & $<0.001^{*}$ & 0.051 & \\
\hline
\end{tabular}




\section{DISCUSSION}

ALA, and its reduced form, DHLA, is effective against conditions in which oxidative stress has a role. It shows beneficial effects in oxidative stress conditions because of its synergistic action with other antioxidants. ALA, which is a universal antioxidant, functions in both aqueous and membrane phases (Tremellen, 2012).

In the present work there was a significant difference between 2 groups as regard occupation and there was a high significant difference between 2 groups as regard duration of marriage. However, Eslamian et al. (2015) reported that there was no significant difference between the studied groups regarding age and duration of marriage.

The present study showed that there was no significant difference between 2 groups. As regard weight, height, and BMI.

Our results were in agreement with study of Haghighian et al. (2015) as they demonstrated that the three were no significant changes in BMI, weight, and physical activity in the subjects after consuming of ALA and placebo.

The current study showed that there was a high significant difference between 2 groups as regard volume after treatment and there was a significant difference between 2 groups as regard count before treatment. Our results were supported by study of Haghighian et al. (2015) as they reported that there were no significant differences in baseline levels of sperm concentration, sperm count, and sperm total motility between the two groups. However, ALA supplementation, compared with placebo, significantly increased sperm concentration and sperm count.

Furthermore, Canepa et al. (2018) showed a statistically significant increase of sperm concentration number of spermatozoa of total motile sperm count and normal sperm morphology after the treatment respect on the baseline.

In the study in our hands, there was a high significant difference between 2 groups as regard total motility after treatment and as regard progressive motility and \% vitality after treatment. There was a significant difference between 2 groups as regard fructose and $\mathrm{PH}$ pus cells after treatment. Our results were in line with study of Ibrahim et al. (2012) as they reported that there was a significant change in sperm motility in all concentration used. However, the percentages of changes were different for each of the concentration groups. The percentage of motile sperm increased dramatically, from $112.8 \%$ to $251.0 \%$. The increasing phase pattern change reversed following introduction of more concentrated solutions of ALA.

According to Raaia et al. (2012), they showed that ALA could work with its protective mechanisms (antioxidant and immune-modulator), enhancing the testicular function. According to previous studies with antioxidants, they expected an improvement mainly in sperm motility, but a surprising finding was the effect of the ALA on the count (P 0.001) after the third month of therapy; this could be related to the decrease in DNA fragmentation and the hypothesized protective role of the germ cells. 
In the study of Ibrahim et al. (2011), the most significant changes on sperm motility could be seen in sperm population isolated after 2 and 4 minutes of separation. There was no much effect of both antioxidants (coenzyme Q10 (CoQ10) and ALA) on sperm population isolated at 6 minutes. Furthermore, Buanayuda et al. (2019) revealed that the higher progressive motility values in the sperm preparation group with ALA compared to the preparation group without ALA occurred after 3 hours of observation statistically significant, while the higher progressive motility values in the sperm preparation group with ALA compared with the control group from the start of the observation (0 hours). It was statistically significant and higher progressive motility values also occurred in the sperm preparation group without ALA compared to the control group from the initial observation (0 hours). Yeni et al. (2012) found that administration significant $(\mathrm{P}<.05)$ in some reproductive tract measures motility, membrane integrity, and abnormal rate of sperm in adult male rats compared with the placebo group.

The present study showed significant difference between 2 groups as regard TAC after treatment. Our results were supported by study of Haghighian et al. (2015) as they showed that seminal TAC and MDA levels were improved by ALA consumption and the quality of sperm and increased the TAC. Bidmeshkipour et al. (2010) results indicated that TAC levels in the seminal plasma of asthenospermic men were significantly lower than in healthy men. In addition, they found a positive correlation between reduced TAC levels and low sperm motility.

\section{CONCLUSION}

Supplementation with ALA can improve sperm quality. After treatment in oligoasthenoteratozoospermic men, mean count, concentration, and motility increased significantly compared with the placebo group.

\section{REFERENCES}

1. Bidmeshkipour A, Hosseinzadeh A, Gholinezhad $M$ and Biparva P. (2010): Seminal plasma total antioxidant capacity and vitamin-C levels in asthenozoospermia: a case-control study. Tehran Univ Med J., 67: 835-42.

2. Borowczyk K, Krawczyk M, Kubalczyk $P$ and Chwatko G. (2015): Determination of lipoic acid in biological samples. Bioanalysis, 7(14): 1785-1798.

3. Buanayuda GW, Lunardhi $H$ and Mansur IG. (2019): Effect of In-Vitro Alpha Lipoic Acid Addition on Spermatozoa Motility in Sperm Preparation Process. Folia Medica Indonesiana, 55(4): 246-250.

4. Canepa P, Dal Lago A, De Leo C, Gallo M, Rizzo C and Licata E. (2018): Combined treatment with myo-inositol, alpha-lipoic acid, folic acid and vitamins significantly improves sperm parameters of sub-fertile men: A multi-centric study. Eur Rev Med Pharmacol Sci., 22: 7078-7085.

5. Eslamian G, Amirjannati N, Rashidkhani B, Sadeghi MR, Baghestani AR and Hekmatdoost A. (2015): Dietary fatty acid intakes and asthenozoospermia: a case-control study. Fertility and Sterility, 103(1): 190-198.

6. Haghighian HK, Haidari F, Mohammadi-Asl $J$ and Dadfar $M$. (2015): Randomized, triple-blind, placebocontrolled clinical trial examining the effects of alpha-lipoic acid supplement on the spermatogram and seminal oxidative 


\section{AHMED ABD EL-HAMID et al.,}

stress in infertile men. Fertility and Sterility, 104(2): 318-324.

7. Ibrahim SF, Jaffar FHF, Osman $K$ and Syed SF. (2011): Bull spermatozoa motility: optimization of coenzyme q10 and alpha-lipoic acid concentration. IIOAB J., 2: 8-13.

8. Ibrahim SF, Osman K, Das S, Othman AM, Majid NA and Rahman MP. (2012): A study of the antioxidant effect of alpha lipoic acids on sperm quality. Clinics, 63: 545-550.

9. Khosrowbeygi A, Zarghami $\mathbf{N}$ and Deldar Y. (2012): Correlation between sperm quality parameters and seminal plasma antioxidants status. Iran J Reprod Med., 2:58-64.

10.Lu J, Huang Y and Lü N. (2010): WHO Laboratory Manual for the Examination and Processing of Human Semen: its applicability to andrology laboratories in China. Zhonghua Nan Ke Xue., 16(10):867-71.
11.Manda $K$, Ueno $M$, Moritake $T$ and Anzai K. (2011): K.a-Lipoic acid attenuates $\mathrm{X}$-irradiation-induced oxidative stress in mice. Cell Biol Toxicol., 23:129137.

12.Raaia MF, Atyeah AA, Elkhiat YI and Elenany HG. (2012): Treatment of idiopathic asthenozoospermia, either isolated or oligoasthenozoospermia, with $\alpha$-lipoic acid: a placebo-controlled, doubleblind study. Human Andrology, 2(4): 9498.

13.Tremellen K. (2012): Oxidative stress and male infertility-a clinical perspective. Hum Reprod Update, 14:243-58.

14. Yeni D, Fidan AF, Ciğerci Ih, Konuk M, Avdatek F and Gündoğan M. (2012): Effect of $\alpha$-lipoic acid on sperm quality, reproductive tract measures in thinner exposed rats. Andrologia., 44: 74-80. 
تأثثير حمض ألفا ليبويك على مرضى ضعف حركة الحيو انات

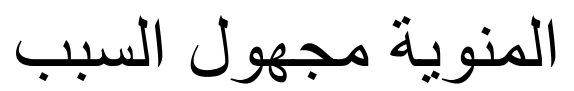

أحمد نبيل محمد عبد الحميد زايد, يحيا محمد إبراهيم هليب, عماد محمود الرويني,

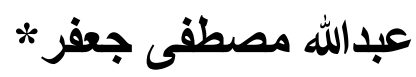

قسمي الأمراض الجلاية و التناسلية والذكورة والباثولوجيا الإكلينيكية*، كلية الطب، جامعة الأزهر

E-mail: zayed3_6@hotmail.com

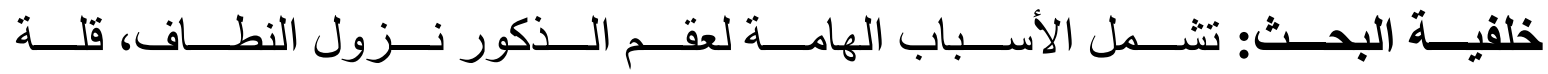

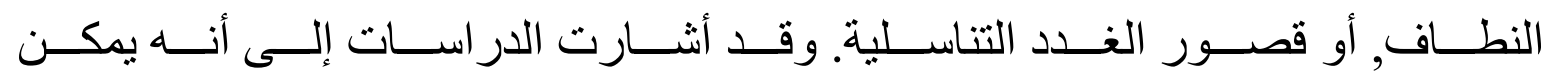
التغلب على بعض مشاكل العقم من خلال تقنية الإنجاب المساعدة.

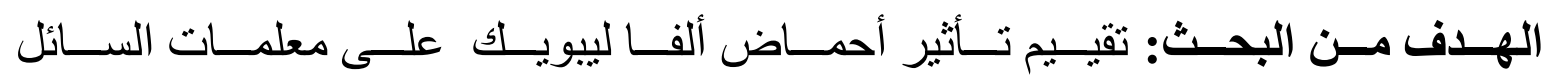

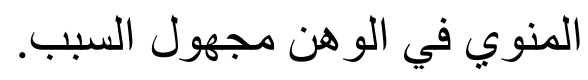

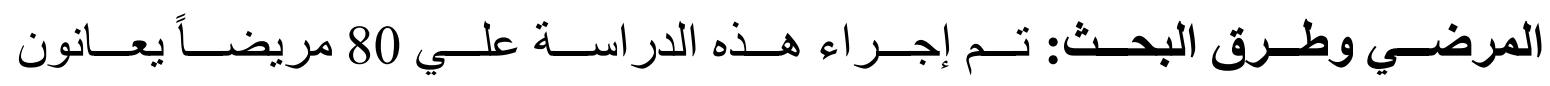

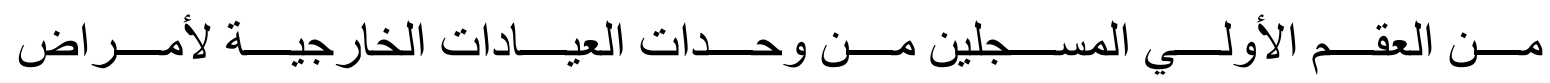

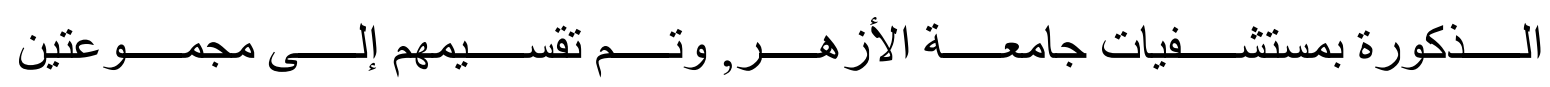

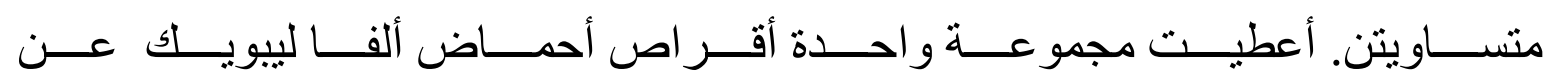

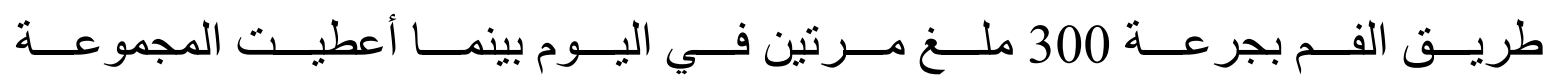

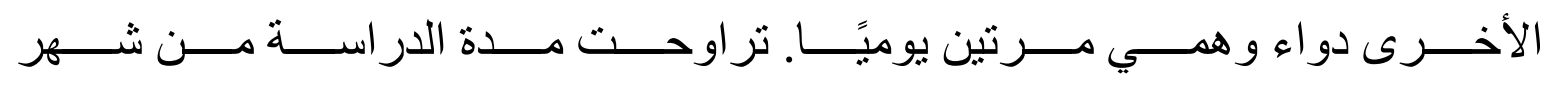
مارس 2020 وحتى شهر سبتمبر 2020.

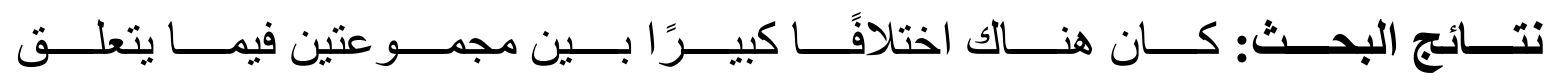

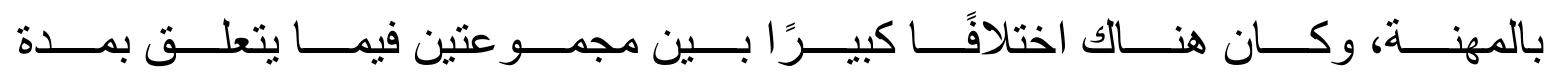

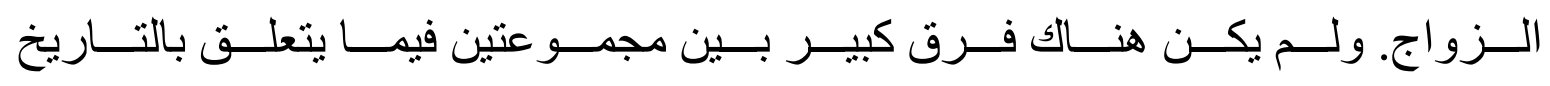

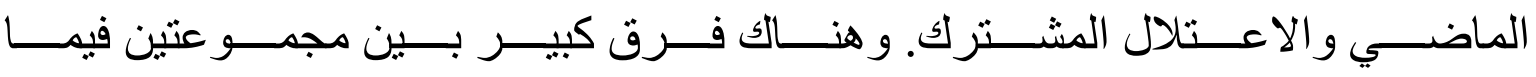

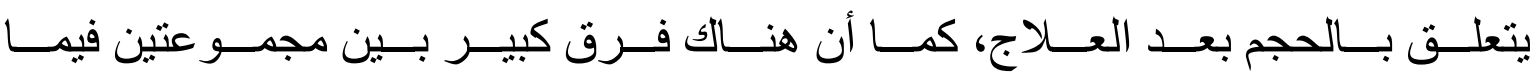




\section{AHMED ABD EL-HAMID et al.,}

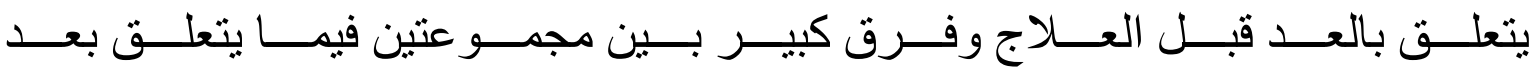

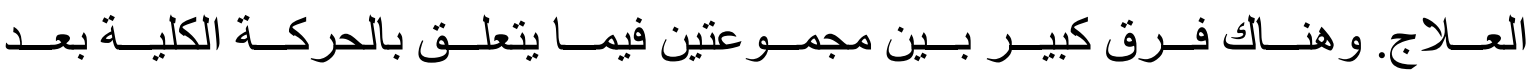

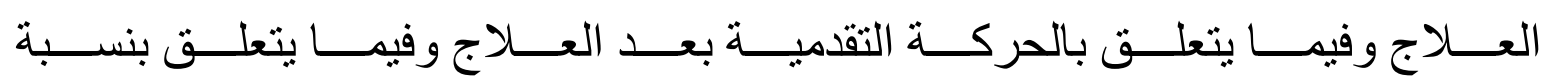

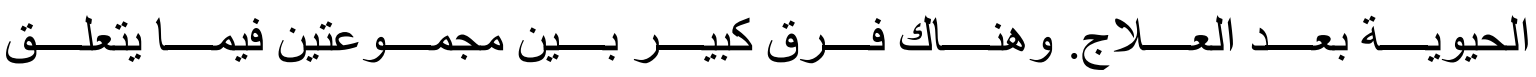

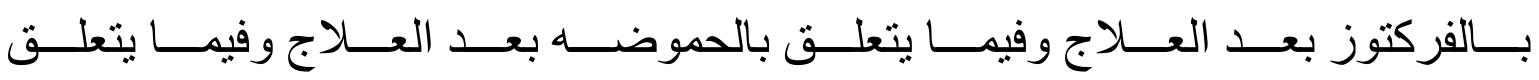
بالخلايا الصديد بعد العلاج.

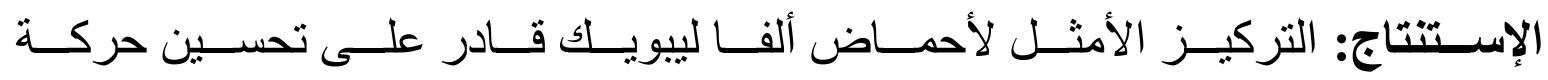

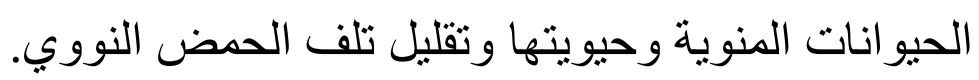

